\title{
USER'S PERCEPTIONS OF SACREDNESS (Case Study: Catholic Churches in Indonesia)
}

\author{
Nita Dwi Estika ${ }^{1^{*}}$, Hanson E. Kusuma ${ }^{2}$, Angela Christysonia Tampubolon ${ }^{3}$, Philipus Bagus Widyawan ${ }^{4}$ \\ ${ }^{1}$ Department of Architecture, Soegijapranata Catholic University, Jl. Pawiyatan Luhur Sel. IV/1, Semarang 50234, Indonesia \\ ${ }^{2}$ Department of Architecture, Institut Teknologi Bandung, Jl. Ganesa 10, Bandung 40132, Indonesia \\ ${ }^{3}$ Department of Architecture, Petra Christian University, Jl. Siwalankerto 121-131, Surabaya 60236, Indonesia \\ ${ }^{4}$ Department of Magister Filsafat Keilahian, Sanata Dharma University, Jl. Kaliurang Km 7, Yogyakarta 55011, Indonesia \\ "Corresponding author; Email: nitadwiestika@gmail.com
}

\begin{abstract}
Sacredness in Catholic Churches arises from two aspects, the purpose and activities of worship and the physical and spatial aspects of a church building. Therefore, this study aimed to reveal the factors that affect sacredness in Catholic churches from the perspective of the worshiper. Exploratory qualitative research was conducted to collect textual data related to the perception of the Catholic church's sacredness through an online questionnaire. Then, explanatory quantitative research was performed to uncover the relationship between the level of sacredness with physical and nonphysical factors. Consequently, the results showed that the 'sacred spirit' factor tends to be more dominant in affecting sacredness than 'sacred object.' Worshipers measure the church's sacredness according to 'devoted reflection,' 'relationship with God,' 'quality of space,' 'enclosure acculturation,' and 'building style'.
\end{abstract}

Keywords: Catholic church; sacredness; worshiper; sacred spirit; sacred object.

\section{INTRODUCTION}

The church, as a building that was originally interpreted so beautifully, was inspired by famous stories in the Old Testament. This includes the Book of Genesis, containing the story of Jacob on his way through Canaan, lying down in a place to sleep, and seeing a ladder to heaven where the angels were going up and down in his dream. Jacob became afraid and said, "How awesome is this place. This is none other than the house of God, this is the gate of heaven." (Genesis 28:17). For centuries, Christians have referred to their churches as Domus Dei (house of God) and porta Caeli (gate of heaven), names that describe a place to live and Him who seeks to meet there. This place describes a building that was created with the intention of entering the presence of God and which should be worthy of its owner. Meanwhile, although God cannot be confined in a building, He chose to present Himself to His people in holy places from the very beginning (Stroik, 2012).

In later Catholic traditions, the church is often referred to as God's building (1 Cor 3: 9). God himself likens Himself to a stone, which the builders formerly threw away but has now, instead, become the capstone. On this foundation, the Church (God's people) was built by the apostles and draws strength from Him. Consequently, the building was given various names, including the house of God (1 Tim 3:15), the residence of His family, the indwelling of God in the Spirit, the tabernacle of God among men (Rev. 21:23), and especially the Holy Temple. These temples were displayed as synagogues, praised by the
Holy Fathers, and correctly likened to the Holy City, New Jerusalem, in the liturgy.

Catholics live up to the church building as a very sacred place, and since their worship activities as a spiritual celebration of the faith are sacred, so must the 'physical container' (Srisadono, 2012). Subsequently, this appreciation is used by the Catholic Church to define the meaning of the holy church. It is expected to consider the sacredness of space within church buildings (Verkaaik, 2013), which allows people to gather for the liturgy. Hence, the church is a holy place where the faithful are in touch with the Divine, and this is, undoubtedly, an important function of the building that sets it apart from the classical temple form in most religions. The Catholic Church acquired the name Domus ecclesiae (house of the Church), and later the word ecclesia was used as an acronym for the living community and the building that houses it (Ratzinger, 2000).

The church building is seen as a space filled with power, that is, tremendous Divine power resides there. Such strength is thought to produce authority and spiritual empowerment and creates an experience that forms the conception of the worshipers (Kieckhefer, 2004). Worshipers, as the subjects of a ministry and users of the church building, have a preference for sacred church elements that encourage feeling the 'presence of God' when worshiping. Therefore, the lack of study that reveals the peoples' preferences of the church building is an important aspect that needs to be explored more deeply for the better service for the worshiper. 
Three studies, which investigated worshipers' perception of church sacredness had interesting findings. Saunders' research found that $81 \%$ of the tourists motivated to visit a church tend not to feel the church's sacredness and consider it a museum, touristic attraction, or a place that only has an aesthetic value (Saunders, 2014). Tourists do not strongly perceive the church's sacredness when they are required to buy tickets for entry, as the admission fee affirms the existence as a tourist attraction, not a place of worship. The second study by Manning, Watkins, and Anthony revealed that worshipers tend to feel devotion, transcendence, and prayerfulness inside a church that has sacred art, such as a crucifix, as well as furnishings with traditional patterns at the sanctuary and tabernacle (Manning et al., 2009). Finally, the study by Estika et al. explained that the meaning of the sacredness of the Catholic church is divided into architectural, worship, and environmental (Estika et al., 2017). Based on the explanation of the three studies above, the research question concerns the aspect that has a greater influence on the church's sacredness, either the purpose, motivation and activity of people or the physical and spatial elements of the building. The study was structured to explore the sacredness of the Catholic church sacredness from the perceptions of the worshiper to answer this problem.

Based on the literature study above, two major group aspects evoke the church's sacredness. The first relates to the personal appreciation or perception by the worshiper and the understanding of the Church as divine. The personal perception of sacredness can awaken respect, reverence, devotion, and personal commitment to living in harmony with the principles or characteristics of sacredness. Sacredness is personal and can be a principle or concept defined by the social community or a material form. Consequently, the meaning of sacredness depends on the purpose and activities undertaken in the church. This interpretation depends on the spiritual journey, which, although affected by the beliefs and practices of institutional or organized worship and religion, is personal and subjective.

The second aspect of sacredness is influenced by the spatial arrangement and physical characteristics of the church building, and this atmosphere is perceived by placing objects, such as sacred art and furnishing, as the reflection of God's existence. Consequently, the limitation of these studies concerns the perspective, which was almost derived from the literature or personal argument. Hence, the gap to be filled in this study is the use of worshipers' perspectives to appreciate human preference.

\section{METHODOLOGY}

This study applied a sequential qualitative method (Creswell, 2008). First, an explorative qualitative method (Groat \& Wang, 2013) was used to identify people's perceptions of the church's sacredness. Then, an explanatory quantitative method (Groat \& Wang, 2013) was used to reveal the relationship between the dimensions and level of sacredness.

\section{The First Research Stage}

In the first stage, data collection was performed through an online questionnaire distributed using nonrandom or snowball sampling to private acquaintances and communities with Catholic members. They were contacted via social media, such as Facebook, Twitter, and WhatsApp, and then asked to spread the questionnaire to other people. Before filling out the questionnaire, the respondents were given an introduction to the study purpose, and though answering did not pose any risk, it was voluntary, and the respondents could choose to fill or not. The initial part of the questionnaire contained requests to fill demographic data while maintaining the respondents' privacy, and the main part comprised open-ended qualitative questions. Since some Catholics have the personal habit of moving from one church to another for worshiping, the respondents were asked to mention a sacred church, according to their perceptions. Then, they were asked to explain the reason they thought the church was sacred, and their answers were analyzed using content analysis to identify and categorize keywords from the respondent's text data. Data collection was conducted for seven days, from August 26 to September 1, 2017, and the total number of respondents was 162 in the age range of 16-60 years. The number of respondents was determined based on the consideration that the collected data was saturated. Consequently, the total number of the churches mentioned by the respondents was 70, and the most mentioned were Hati Kudus Tuhan Yesus Ganjuran Church, Yogyakarta (f: 22), Jakarta Cathedral Church (f: 15), and Saint Antonius Padua Kotabaru Church, Yogyakarta (f: 12).

From the content analysis of the first research stage, 46 variables of physical and non-physical factors that contribute to church sacredness were obtained. The physical factors were 'monumental space scale,' 'altar focal point visible,' 'symbolism and ornamentation,' 'dark-colored material,' 'relatively closed,' 'interior acculturation,' 'unique buildings,' alongside 'classical, colonial, and old buildings.' Others were 'space organization according to standards.' 'exterior acculturation,' 'lighting supports,' 'cathedral church or parish church,' 'adequate parking,' 'many trees,' 'located on a hill,' and 'natural scenery.' Meanwhile, the non-physical factors were 'quiet and solemn atmosphere,' 'feels spacious,' 'reflection,' 'comfortable and safe buildings,' 'holy buildings,' 'good acoustics,' 'air comfort,' 'complete 
Table 1. Literature study of the church's sacredness

\begin{tabular}{|c|c|c|c|c|c|c|c|c|}
\hline & $\begin{array}{c}\text { Presence of } \\
\text { God } \\
\text { (transcendence) }\end{array}$ & $\begin{array}{c}\text { Blessing- } \\
\text { dedication of } \\
\text { Church }\end{array}$ & $\begin{array}{c}\text { Personal } \\
\text { appreciation/ } \\
\text { perceived }\end{array}$ & $\begin{array}{c}\text { Intrinsic } \\
\text { orientation }\end{array}$ & $\begin{array}{c}\text { Activity } \\
\text { (worship) }\end{array}$ & $\begin{array}{c}\text { Physical } \\
\text { arrangement }\end{array}$ & $\begin{array}{l}\text { Object that } \\
\text { reflects the } \\
\text { existence of God }\end{array}$ & $\begin{array}{l}\text { Sacred art } \\
\text { and } \\
\text { furnishing }\end{array}$ \\
\hline (Dimock, 1964a) & & & & & & & $\mathrm{V}$ & $\mathrm{V}$ \\
\hline (Dimock, 1964b) & & & $\mathrm{v}$ & & & & & \\
\hline (Burke, 1967) & & & & & $\mathrm{v}$ & & & \\
\hline (Thomas, 1994) & & & & & $\mathrm{v}$ & & & \\
\hline (Hill et al., 2000) & $\mathrm{v}$ & & $\mathrm{v}$ & & & & $\mathrm{v}$ & \\
\hline (Riley, 2000) & & $\mathrm{v}$ & & & & & $\mathrm{v}$ & $\mathrm{v}$ \\
\hline (Turner, 2000) & & & & & & & & $\mathrm{v}$ \\
\hline $\begin{array}{l}\text { (Manning et al., } \\
\text { 2009) }\end{array}$ & & & $\mathrm{v}$ & & & $\mathrm{v}$ & $\mathrm{v}$ & $\mathrm{v}$ \\
\hline $\begin{array}{l}\text { (Roccasalvo, } \\
\text { 2009) }\end{array}$ & $\mathrm{v}$ & & & & & & $\mathrm{v}$ & $\mathrm{v}$ \\
\hline (Hoffman, 2010) & & & & & & $\mathrm{v}$ & & $\mathrm{v}$ \\
\hline (Parker, 2010) & & & & & & $\mathrm{v}$ & & \\
\hline $\begin{array}{l}\text { (Herzog et al., } \\
\text { 2011) }\end{array}$ & & & $\mathrm{v}$ & & & $\mathrm{v}$ & & \\
\hline $\begin{array}{l}\text { (Heatubun, } \\
\text { 2012) }\end{array}$ & & & $\mathrm{v}$ & & & & & \\
\hline (Lang, 2012) & & & & & & & & $\mathrm{v}$ \\
\hline $\begin{array}{l}\text { (Srisadono, } \\
\text { 2012) }\end{array}$ & $\mathrm{v}$ & & & & & $\mathrm{v}$ & & $\mathrm{v}$ \\
\hline (Verkaaik, 2013) & & & $\mathrm{v}$ & & $\mathrm{v}$ & & & \\
\hline (Baker, 2014) & & & & & & $\mathrm{v}$ & $\mathrm{v}$ & \\
\hline (Saunders, 2014) & & & & $\mathrm{v}$ & $\mathrm{v}$ & & & \\
\hline $\begin{array}{l}\text { (Trisno et al., } \\
\text { 2014) }\end{array}$ & & & & & $\mathrm{v}$ & & & $\mathrm{v}$ \\
\hline $\begin{array}{l}\text { (Trisno et al., } \\
\text { 2015) }\end{array}$ & & & & & $\mathrm{v}$ & & & $\mathrm{v}$ \\
\hline (Lidov, 2015) & & & & & $\mathrm{v}$ & $\mathrm{v}$ & & $\mathrm{v}$ \\
\hline (Meagher, 2015) & & & & $\mathrm{v}$ & & $\mathrm{v}$ & & \\
\hline $\begin{array}{l}\text { (Baring et al., } \\
\text { 2016) }\end{array}$ & & & $\mathrm{v}$ & & & & & \\
\hline (Costa \& & & & $\mathrm{v}$ & & & $\mathrm{v}$ & & \\
\hline Bonetti, 2016) & & & & & & & & \\
\hline $\begin{array}{l}\text { (Hildebrand et } \\
\text { al., 2016) }\end{array}$ & $\mathrm{v}$ & & $\mathrm{v}$ & & $\mathrm{v}$ & & & \\
\hline (Saward, 2017) & & $\mathrm{v}$ & & & & & & \\
\hline $\begin{array}{l}\text { (Swanson, } \\
\text { 2017)s }\end{array}$ & & & $\mathrm{v}$ & & & & & \\
\hline (Trisno, 2017) & & & & & $\mathrm{v}$ & $\mathrm{v}$ & & $\mathrm{v}$ \\
\hline (Eilouti, 2017) & & & & & & $\mathrm{v}$ & & \\
\hline (Meagher, 2018) & & & $\mathrm{v}$ & & & $\mathrm{v}$ & & \\
\hline Sum & 4 & 2 & 11 & 2 & 9 & 12 & 6 & 12 \\
\hline
\end{tabular}

Table 2. Sample questions with semantic and Likert differential methods

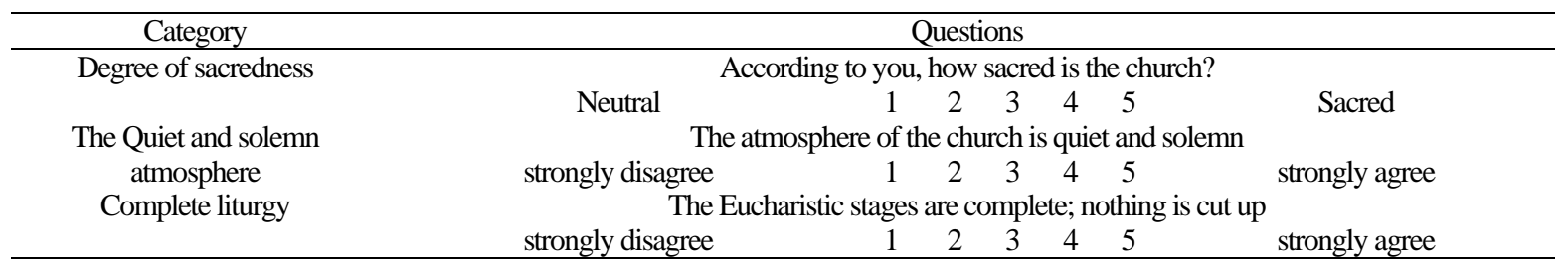

liturgy,' and 'organized custodian.' Others were 'beautiful choir,' 'effective homilies,' 'respectful worship,' 'spiritual experience,' 'believe God 'lives,' and 'meet with God.' 'habitual to church,' 'spontaneity,' 'not knowing each other,' and 'respectful worshiper.' Additional non-physical factors were 'orderly worshiper,' 'relatively few worshipers,' 'majority of elderly worshipers,' 'place of worship,' 'variety of activities,' 'not crowded,' 'reflective,' 'environmental support,' 'cool environment,' 'natural sound,' and 'easy access.' The content analysis results of the above-mentioned factors were used to formulate the close-ended questions in the second stage.

\section{Second Research Stage}

In the second research stage, data collection was performed by distributing an online questionnaire containing close-ended questions whose substance came from the qualitative data obtained from the first stage. The online questionnaires were distributed via social media, such as Facebook, Twitter, and WhatsApp. Then, the respondents were asked to assess the sacredness level of a nearby or frequently visited church by answering 47 questions indicating the physical and nonphysical qualities of this church. Except for the one on the degree of church sacred- 
ness, each question was answered using a 5-point Likert scale. Table 1 shows some sample questions from the close-ended online questionnaire.

Data were collected within 15 days, from October 10 to 25, 2017. There were a total number of 312 respondents in the age range of 16-62 years, residing in Klaten, Yogyakarta, Sleman, and Jakarta. Then, the number of samples was determined based on the STV ratio (Bryant \& Yarnold, 2011)' and a total of 118 nearby or frequently visited churches were stated. The most mentioned were Saint Antonius Padua Kotabaru Church, Yogyakarta (f: 46), Saint Maria Ratu Bayat Church, Klaten (f: 27), Saint Maria Assumpta Klaten Church (f: 14), and Saint Maria Assumpta Babarsari Church, Yogyakarta (f: 14).

The data collected in the second research stage were numerical data, analyzed quantitatively using principal component analysis (PCA) and factor analysis (FA). Factor analysis was used to find dimensions and latent variables to represent measured variables of the physical and nonphysical factors constituting the Catholic church's sacredness. Subsequently, these dimensions were used as independent variables, and the degree of the church building's sacredness was used as the dependent variable in the regression analysis to reveal the dominant affecting dimensions.

\section{RESULTS AND DISCUSSION}

The Cronbach's alpha value in the data used in this analysis is 0.92 , and a high score indicates that each respondent's answer is consistent and highly correlated with the answers of the other participants (Lavrakas, 2008). In PCA, the determination of the number of major components was done using Kaiser's stopping rule (1960), which employs an eigenvalue greater than one. A value of more than one indicates that the variability exceeds that of the operational or measured variables, enabling its use to represent these variables. Furthermore, factor analysis was used to obtain and facilitate the naming of latent variables or dimensions through the varimax rotation method to ensure there were no correlations.

The PCA results of the physical and nonphysical variables of the Catholic church's sacredness show that eleven major components had an eigenvalue above one, with a cumulative variability percentage of $60.66 \%$. This score is considered sufficient to describe and represent the 47 measured variables. Table 3. shows the latent variables from the factor analysis results, and eleven were found to represent the perception of Catholic church sacredness. They were 'quality of space,' 'devoted reflection,' 'natural environment,' 'relationship with God,' 'acoustics,' 'enclosure acculturation,' 'orderly worshiping,'

Table 3 Latent variables from the factor analysis results with varimax rotation of 11 main components

\begin{tabular}{|c|c|c|c|}
\hline \multirow[t]{2}{*}{ Measured variable } & \multicolumn{3}{|c|}{ Latent variable } \\
\hline & (1) Quality of space & (2) Devoted reflection & (3) Natural environment \\
\hline Cronbach's $\alpha$ & .83 & .84 & .82 \\
\hline Mean & 3.91 & 3.60 & 3.26 \\
\hline Std. Dev. & .64 & .73 & .79 \\
\hline Monumental space scale & .80 & & \\
\hline Feels spacious & .67 & & \\
\hline Symbolism and ornamentation & .56 & & \\
\hline Comfortable and safe buildings & .55 & & \\
\hline Altar focal point and visible & .51 & & \\
\hline Cathedral church or parish church & .48 & & \\
\hline Reflection & .43 & & \\
\hline Lighting supports & .40 & & \\
\hline Unique buildings & .40 & & \\
\hline Space organization according to standards & .36 & & \\
\hline Respectful worshipers & & .69 & \\
\hline Orderly worshipers & & .64 & \\
\hline Respectful worshiping & & .63 & \\
\hline Reflective & & 62 & \\
\hline Quiet and solemn atmosphere & & .54 & \\
\hline Good acoustics & & .44 & \\
\hline Air comfort & & .48 & \\
\hline Cool environment & & & .69 \\
\hline Not crowded & & & .67 \\
\hline Natural sound & & & .66 \\
\hline Natural scenery & & & .64 \\
\hline Environmental support & & & .63 \\
\hline Many trees & & & .60 \\
\hline Adequate parking & & & .57 \\
\hline
\end{tabular}


Table 3 (continued). Latent variables from the factor analysis results with varimax rotation of 11 main components

\begin{tabular}{lrrrr}
\hline & \multicolumn{5}{c}{ Latent variable } \\
\cline { 2 - 6 } Measured variable & (4) Relationship with God & (5) Acoustics & $\begin{array}{r}\text { (6) Enclosure } \\
\text { acculturation }\end{array}$ & (7) Orderly worshiping \\
\hline Cronbach's $\alpha$ & .81 & .66 & .46 & .63 \\
Mean & 4.08 & 3.81 & 3.53 & .79 \\
Std. Dev. & .74 & .83 & & .81 \\
Believe God 'lives' & $\mathbf{. 1}$ & & \\
Meet with God & $\mathbf{. 7 1}$ & & \\
Spontaneity & $\mathbf{. 6 4}$ & & \\
Habitual to church & $\mathbf{. 6 1}$ & & \\
Spiritual experience & $\mathbf{. 5 0}$ &
\end{tabular}

Effective homilies $\quad \mathbf{. 6 8}$

Beautiful choir $\quad \mathbf{6 1}$

$\begin{array}{ll}\text { Exterior acculturation } & .74\end{array}$

Interior acculturation $\quad \mathbf{. 5 1}$

Place of worship $\quad . .37$

$\begin{array}{lr}\text { Complete liturgy } & \mathbf{6 9}\end{array}$

Organized custodian $\quad \mathbf{6 0}$

\begin{tabular}{lrrrr}
\hline & \multicolumn{4}{c}{ Latent variable } \\
\cline { 2 - 5 } Measured variable & $\begin{array}{c}\text { (8) Worshiper } \\
\text { characteristics }\end{array}$ & $\begin{array}{c}\text { (9) Building } \\
\text { style }\end{array}$ & (10) Location & (11) Lack of interaction \\
\hline Cronbach's $\alpha$ & .57 & .37 & .34 & 2.70 \\
Mean & 2.28 & 2.83 & 3.32 & 1.27 \\
Std Dev & .91 & .83 & .59 & \\
Majority of elderly worshipers & $\mathbf{. 7 6}$ & & \\
Relatively few worshipers & $\mathbf{. 7 5}$ & & \\
Dark-colored material & & $\mathbf{. 6 9}$ & $\mathbf{. 6 2}$ \\
Relatively closed & & $\mathbf{. 5 0}$ & $\mathbf{. 4 0}$ \\
Classical, colonial, and old buildings & & & $\mathbf{. 3 5}$ \\
Easy access & & & $\mathbf{. . 5 8}$ \\
Holy buildings & & & \\
Variety of activity & & & $\mathbf{. 7 5}$ \\
Located on a hill & & & \\
Not knowing each other & & & \\
\hline
\end{tabular}

'worshiper characteristics,' 'building style,' 'location,' and 'lack of interaction.' Table 3 also shows the Cronbach's $\alpha$ values, mean, and standard deviation calculated from the measured variables that contributed to the latent variables.

Next, the results of the regression analysis conducted to uncover causal relationships between the physical and nonphysical dimensions and sacredness are shown in Table 4. Dimensions that significantly affect the degree of sacredness, ordered from the large to small, were 'devoted reflection' $(\beta=0.37)$, 'relation to God' $(\beta=0.3)$, 'quality of the space' $(\beta=$ $0.21)$, 'enclosure acculturation' $(\beta=0.21)$, and 'building style' $(\beta=0.16)$. (See Table 4 for the regression analysis results).

The two dimensions that affected sacredness the most were spirituality and worship. 'Devoted reflection' represents worshiping with devotion during the service, orderliness, evoking reflection, and a quiet atmosphere, which can create respectfulness. Meanwhile, the 'relationship with God' dimension represents God's presence, such as believing God 'lives,' meeting Him, evoking a sense of place, habitual to church, and a spiritual experience, which tends to be subjective. These two dimensions are composed of the intrinsic affective and cognitive orientation and response patterns that relate directly to the individual goals of the respondent in worshiping in a church (Meagher, 2015). In addition, personal cognitive elements develop the conception of sacredness (Henrie, 1972).

Consequently, the dimensions of worship that affect the sacredness of a church building correspond with those expressed in the first group aspect and the literature review. The premise was that the meaning of sacredness is influenced by the purpose and activities undertaken, and it is personal and subjective. Also, the result of this study is parallel with the study on environmental preferences. Individual religiosity of perceptual and religious orientation has a strong relationship to community beliefs, which influences the religious environment. In addition, affective responses to religious settings are appropriate products between designs and certain religious motivations (Kaplan et al., 1989). 
Table 4. Regression of the Church's Physical-Nonphysical Dimensions and Degree of Sacredness. $R^{2}=0.37 . p$ $=<.0001$

\begin{tabular}{lcc}
\hline Term & Estimate $(\beta)$ & Prob $>|\mathrm{t}|(\mathrm{p})$ \\
\hline Devoted reflection & .374 & $<.0001$ \\
Relationship with God & .299 & $<.0001$ \\
Quality of space & .214 & $<.0001$ \\
Enclosure acculturation & .205 & $<.0001$ \\
Building style & .155 & .0008 \\
Natural environment & .088 & .0571 \\
Acoustics & .081 & .0802 \\
Lack of interaction & .069 & .1352 \\
Location & -.062 & .1812 \\
Orderly worshiping & .058 & .2076 \\
Worshiper characteristics & -.024 & .6000 \\
\hline
\end{tabular}

Sacredness is a transcendental, dialectical, vertical relationship with the universe and God. Also, sacred centers orientate individuals and groups "vertically," creating a spatial relationship between the celestial powers above and the forces present in the world (Kilde, 2008). Meanwhile, research showed that the Mormon community categorizes the level of sacred space into mystico-religious, homelands, and historical (Jackson \& Henrie, 1983). Although the present respondents had different beliefs from this previous study, similar findings were revealed. People perceive sacred space when they believe there is contact between human and divine power through religious experience, and this is a representation of the 'relationship with God' dimension.

Deep personal experience of the Divine influences the believer's understanding of the sacred space, and this conception comes from three sources (Kilde, 2008). First, powers that are divine, supernatural, or associated with God. Second, social forces or those associated with various social hierarchies, especially clerics. Third, personal strength or the feeling of growing spiritual strength that individuals acquire from the experience of God. In Catholicism, people believe the presence of the Lord Jesus is real or substantive in the bread and wine consecrated in the Eucharist, and such experiences lead to the belief in God.s real presence in their church.

The results of this study indicate that the worship dimensions, of which there are several, are the most dominant in affecting sacredness. Although ritual activities are important to create a devout atmosphere to enable people to meet with God, the sacredness felt depends more on personal faith (Bunyamin, 2012). Sacredness is created by each individual and expressed in worship, and most felt when 'devoted reflection' and 'relationship with God' occur. These two factors represent a 'sacred spirit' as the conception of the sacredness by the people who come to a church to worship.
Also, two dimensions that affect sacredness are the spatial and physical dimensions of the church. Worshipers choose a place to pray based on comfort, hence each person considers spatial factors when deciding to continue worshiping in the same place (Meagher, 2018). This condition is called 'place stability' and is the foundation of Catholic church sacredness (Baker, 2014). The human basic need for a sense of place, belonging, and home are fulfilled in places with stability, which are provided with safety, remain unchanged, and can make people stay (Baker, 2014). Although worshipers can ideally pray in any situation, they will be greatly helped by the conditions in the place of prayer. Therefore, place and ritual factors are important in creating sacredness.

The dimension 'quality of space' represents the monumental scale of the space, which feels spacious, safe, and comfortable, and has symbolism, ornamentation, and a visible altar as the focal point. Regarding monumental scale, there is the influence of religious monumental architecture (RMA) in supporting the human sensitivity and psychological mechanism of religious doctrine and worship (Joye \& Verpooten, 2013). RMA creates an emotional response and adaptive 'sensitivity for bigness' that supports the building process of the religious community (Joye \& Verpooten, 2013). Also, vertical geometrical shapes are strongly associated with sacredness (Costa \& Bonetti, 2016). The dimension of space quality is further explained by the placement of sacred art, furnishings, signs, icons, and relics that have equivalent meaning, as found in the second literature review group. Sacredness can also be found in objects that are considered sacred by certain social groups.

The 'enclosure acculturation' dimension represents the acculturation quality of the exterior and interior elements. Acculturation means an intercultural encounter and the acceptance of foreign elements at a deeper level of enculturation, which is the integration of Christian faith in local culture (Martasudjita, 2005). Individuals with certain norms, cultural, and social backgrounds have their definitions and interpretations of the sacredness framework and consider certain objects sacred (Sutrisno \& Putranto, 2005). Meanwhile, the 'building style' dimension represents dark-colored materials, relatively closed buildings, and classical, colonial, and old buildings.

Therefore, the 'enclosure acculturation' and 'building style' dimensions represent the visual quality of a church building as stored in people's collective memory, which tends to be regarded as a constituent element of its identity. These elements are related to sacredness as understood by the church. Sacredness is influenced by the buildings, hence 
'sacred objects,' as contributors to church identity through the building's physical and spatial character, are representations of and containers that accommodate this function.

The exploration study of affective reactions to churches showed that exterior characteristics, such as a building of worship are created by aspects of visual richness, age, and building care (Herzog et al., 2011). A sense of tranquility is strongly associated with reflection and positively correlates with recovery or restoration and reflection (Herzog et al., 2011). Meanwhile, a study of sacredness perception of heritage religious sites was conducted, although based on the perspective of Western tourists at Thai Buddhist sites (Levi \& Kocher, 2012). Subsequently, similarities were observed between these previous results and the present research. The earlier study shows the factors related to the perception of sacredness are religious activity (28\%), which represents 'sacred spirit,' and religious symbols (24\%), which signify 'sacred objects.'

In conclusion, from the explanation above, a model of the factors that affect sacredness, as seen in Figure 1, was proposed. Sacredness is influenced by 'devoted reflections,' which are representations of worship activities, and by 'relationship with God,' which is a conception held towards these activities. These two factors are referred to as 'Sacred Spirit,' defined as the conception of sacredness as the essence of appreciation and expression of the Catholic faith (spirituality and religiousness) by the people who came to worship. In addition to the above factors, sacredness is also influenced by 'Sacred Object,' which represents the spatial and physical qualities of the church as the embodiment of the Catholic faith.

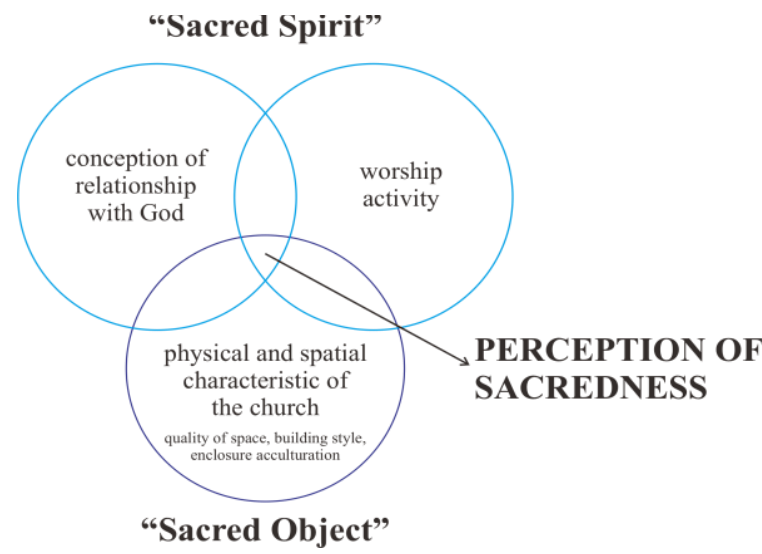

Fig. 1. The hypothetical model of worshiper's perception of sacredness based on the sense of place model (Canter, 1977)
This hypothetical model is the result of data taken before the Covid-19 pandemic, as the prolonged situation has made realizing the factors creating the Catholic church's sacredness difficult because worship cannot be performed directly in the building. In the future, if the people can worship, they will likely be unable to come every week, or their attendance will be limited. Hence, this condition to stay at home is a big problem so long as the understanding of sacredness is only limited by the formation of the physical aspect of the church building.

The traditional paradigm of the Church is the gathering of people as a community, therefore, membership is determined by the participation and involvement of the faithful. Furthermore, the continual movement, according to the guidance of the Spirit, is the understanding of Solid Church, which is a Church that is constant and remains in changing situations. The Covid-19 pandemic situation forced the Church to transform and awaken to a more dynamic and connected meaning, which has become a new model (Pambudi, 2020).

In addition, the Church flows, follows, and changes with the situation of the times. During this pandemic, it lived as the presence of God in the house of every worshiper, which became sacred due to His presence. This pandemic leads the Church in a spread or diasporic mode, and related to that process, is called Liquid Church (Ward, 2001). This conception is similar to the concept of Gereja Diaspora by Mangunwijaya, which emphasizes contemporary culture, communication, and the informality of Churches facing changes (Mangunwijaya, 1999). Churches have to be relevant to the current and future situation. Therefore, a combination of Solid-Liquid Church needs to be applied to achieve success in proclaiming the Kingdom of God and maintaining the Christian spirituality of Catholics.

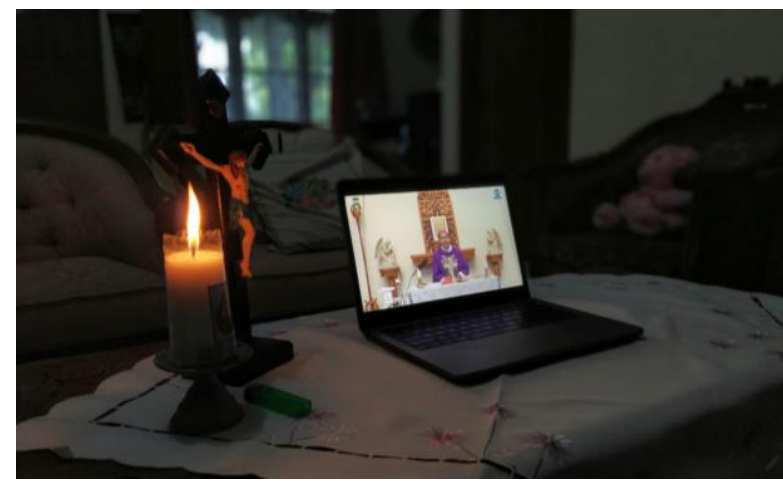

Fig. 2. Altar setting in each house during online mass 
Online worship (Figure 2.), which is a means of experiencing faith in contemporary culture, occurred, in this case, due to the pandemic demands. The conditions of social restrictions for gathering in large numbers occasionally caused disappointment among members. Although this is understandable, awareness is required to educate people that when the Church insists on performing activities involving many people, it is not liquid and becomes irrelevant. The persistence in worshiping online in respective houses shows their longing to meet Jesus. When worshiping online, each house prepares sacred objects, such as crosses and candles, and the placement of these objects in this limited situation also creates sacredness. The pandemic reinforces that sacredness is more dependent on the individual's relationship with God, which is strengthened by worship activities rather than church buildings. Hence, worship can be done anywhere, and the most important factor is the belief in the faith and sacred spirit of the people.

\section{CONCLUSION}

Worshipers' perceptions of the sacredness of Catholic churches were analyzed to reveal the latent variables of factors that affect sacredness. This study showed that five dominant dimensions, which can be divided into two groups, affect the church's sacredness. The first and most influential is 'Sacred Spirit,' defined as the appreciation and expression of the Catholic faith and represented by the qualities, 'devoted reflection' and 'relation to God.' Conversely, the second group of dimensions that influences sacredness is 'Sacred Object,' as the embodiment of the Catholic faith as represented by 'quality of space,' 'enclosure acculturation,' and 'building style.'

In this study, the knowledge of the church's sacredness and the influencing factors were based on the perceptions of Catholic worshipers. Although a high Cronbach's alpha value was obtained, the respondents were mostly residents from 125 churches in Klaten, Yogyakarta, Sleman, and Jakarta, Indonesia. Therefore, their perceptions do not represent that of general worshipers but belong to a small portion from a particular region in the country. Other groups and cultures may have varying perspectives, as different people have their definitions of sacredness based on their cultural and social backgrounds. Another limitation was that only people interested in participating completed the online surveys. Hence, this research could be replicated with other groups to improve the reliability of the findings. The method of collecting data by convenience sampling was also expected to limit the generalization of the findings.

\section{REFERENCES}

Baker, S. J. (2014). Stabilitas or Mobilitas? Sacred Architecture, 26, 31-33.

Baring, R. V., Erasga, D. S., Garcia, L. dl R., Peracullo, J. C., \& Ubaldo, L. R. (2016). The Young and the Sacred: An Analysis of Empirical Evidence from the Philippines. Young, 25(1), 26-44. https://doi.org/10.1177/11033088 16665013

Bryant, F. B., \& Yarnold, P. R. (2011). PrincipalComponent Analysis and Exploratory and Confirmatory Factor Analysis. In L. G. Grimm \& P. R. Yarnold (Eds.), Reading and Understanding Multivariate Statistics, 99-136. American Psycological Association.

Bunyamin, A. S. (2012). Sakral dan Profan dalam Kaitan dengan Ritus Tubuh: Suatu Telaah Filsafati Melalui Agama dan Konsep Diri. Melintas, 23-38.

Burke, M. (1967). The Role of Song In the New Liturgy. Dominicana, 111-117.

Canter, D. (1977). The Psychology of Place. London: Architectural Press.

Costa, M., \& Bonetti, L. (2016). Geometrical Factors in the Perception of Sacredness. Perception, $O(0), \quad 1-27$. https://doi.org/10.1177/030100661 6654159

Creswell, J. W. (2008). Research design: qualitative, quantitative, and mixed methods approaches. California: Sage Publications, Inc.

Dimock, G. (1964a). Architecture and Liturgy. Dominicana, 131-140.

Dimock, G. (1964b). Liturgy and Community. Dominicana, 349-159. https://doi.org/10.1177/00405 71X4504830102

Eilouti, B. (2017). Sinan and Palladio: A comparative morphological analysis of two sacred precedents. Frontiers of Architectural Research, 6, 231-247. https://doi.org/10.1016/j.foar.2017. 03.003

Estika, N. D., Kurniati, F., Kusuma, H. E., \& Widyawan, F. B. (2017). Makna Kesakralan Gereja Katolik. Jurnal Lingkungan Binaan Indonesia, 6(3), 195-202. https://doi.org/10.32315/jlbi.6. 3.195

Groat, L., \& Wang, D. (2013). Architectural Research Method (Vol. 3, Issue 2). New Jersey: John Wiley \& Sons. http://repositorio.unan.edu.ni/ 2986/1/5624.pdf

Heatubun, F. S. (2012). Liturgi Sakral yang Indah, Liturgi Indah yang Sakral. Melintas, 39-60. https://doi.org/10.26593/mel.v28i1.288.39-60

Henrie, R. L. (1972). The Perception of Sacred Space: the Case of Utah and Other Sacred Places in Mormondom. Brigham Young University. 
Herzog, T. R., Gray, L. E., Dunville, A. M., Hicks, A. M., \& Gilson, E. A. (2011). Preference and Tranquility for Houses of Worship. Environment and Behavior, 45(4), 504-525. https://doi.org/ 10.1177/0013916511410422

Hildebrand, D. Von, Mcneil, B., \& Crosby, J. F. (2016). The Second Theme of Architecture: Artistic Beauty from Aesthetics Vol. II. Sacred Architecture, 30, 21-25.

Hill, P. C., Pargament, K. I., Hood, R. W., McCullough, J. . M. E., Swyers, J. P., Larson, D. B., \& Zinnbauer, B. J. (2000). Conceptualizing Religion and Spirituality: Points of Commonality, Points of Departure. Journal for the Theory of Social Behaviour, 30(1), 51-77. https://doi. org/10.1111/1468-5914.00119

Hoffman, D. R. (2010). Seeking the Sacred in Contemporary Religious Architecture (M. J. Tevesz (ed.)). Ohio: The Kent State University Press. https://doi.org/10.16926/i.2017.03.16

Jackson, R. H., \& Henrie, R. (1983). Perception of Sacred Space Perception of Sacred Space. Journal of Cultural Geography, 3(2), 94-107.

Joye, Y., \& Verpooten, J. (2013). An Exploration of the Functions of Religious Monumental Architecture From a Darwinian Perspective. Review of General Psychology, 17(1), 53-68. https://doi. org/10.1037/a0029920

Kaplan, R., Kaplan, S., \& Brown, T. (1989). Environmental Preference: A Comparison of Four Domains of Predictors. Environment and Behavior, 21(5), 509-530. https://doi.org/10. 1177/0013916589215001

Kieckhefer, R. (2004). Theology in Stone: Church Architecture from Byzantium to Berkeley. New York: Oxford University Press, Inc. http://repositorio.unan.edu.ni/2986/1/5624.pdf

Kilde, J. H. (2008). Sacred Power, Sacred Space: An Introduction to Christian Architecture and Worship. New York: Oxford University Press, Inc.

Lang, U. M. (2012). The Language of Babylon and Expression of the Sacred. Sacred Architecture, 22, 34-37.

Lavrakas, P. J. (2008). Encyclopedia of Survey Research Methods. United State of America: SAGE Publications, Inc.

Levi, D., \& Kocher, S. (2012). Perception of Sacredness at Heritage Religious Sites. Environment and Behavior, 45(7), 912-930. https://doi.org/ $10.1177 / 0013916512445803$

Lidov, A. (2015). Creating the Sacred Space. Hierotopy as a new field of cultural history. Spazi $i$ Percorsi Sacri. I Santuari, Le Vie, i Corpi, Civilta e Religioni, 61-90. http://hierotopy.ru/contents/LIDOV_Hierotopy_Spazi_sacri_2015.pdf \% 5CnAll Papers/L/Lidov - Creating the Sacred
Space. Hierotopy as a new field of cultural history.pdf

Mangunwijaya, Y. B. (1999). Gereja Diaspora. Yogyakarta: Kanisius.

Manning, K. C., Watkins, N. J., \& Anthony, K. H. (2009). The People of The Steeple? An Examination of Sacramental Architecture among Parishoners. Sacred Architecture, 16, 17-19.

Martasudjita, E. (2005). Inkulturasi Gereja Katolik Di Indonesia: Problematik, pengertian dan teologi inkulturasi. Studia Philosophica et Theologica, 5(2), 127-145.

Meagher, B. R. (2015). Perceiving Sacred Space: Religious Orientation Moderates Impressions of Religious Settings. Environment and Behavior, 1-19. https://doi.org/10.1177/0013916515581626

Meagher, B. R. (2018). Deciphering the religious orientation of a sacred space: Disparate impressions of worship settings by congregants and external observers. Journal of Environmental Psychology, 55, 70-80. https://doi.org/10.1016/ j.jenvp.2017.12.007

Pambudi, H. S. W. (2020). Gereja yang Cair: Gereja sebagai Ruang Perjumpaan dan Komunikasi. Universitas Sanata Dharma Yogyakarta.

Parker, T. K. (2010). The Modern Church in Rome: On the Interpretation of Architectural and Theological Identities, 1950-80. The University of Texas at Austin.

Ratzinger, J. (2000). Sacred Places: The Significance of the Church Building. In The Spirit of the Liturgy. California: Ignatius Press.

Riley, P. J. (2000). Spanish Colonial Sacred Architecture: The New Parish Church of San Juan Capistrano. Sacred Architecture, 19-21.

Roccasalvo, J. L. (2009). Called to Beauty through Iconography: Sacred Images in The Christian Tradition. Sacred Architecture, 16, 26-29.

Saunders, V. D. (2014). The Churches of Venice: Sacred Places of Museum Spaces. Journal of Interpretation Research, 61-64.

Saward, J. (2017). The Poverty of the Church and the Beauty of the Liturgy. Sacred Architecture, 31, 11-17.

Srisadono, Y. D. (2012). Konsep Sacred Space dalam Arsitektur Gereja Katolik. Melintas, 28(2), 182206.

Stroik, D. G. (2012). The Church Building as a Sacred Place: Beauty, Transcendence, and the Eternal. Chicago: Liturgy Training Publications.

Sutrisno, M., \& Putranto, H. (2005). Teori-Teori Kebudayaan. Yogyakarta: Kanisius.

Swanson, C. (2017). The Human Figure and Contemporary Sacred Art. Sacred Architecture, 31, 28 30.

Thomas, J. A. (1994). Theory, Meaning \& Experience In Church Architecture. University of Sheffield. 
Trisno, R. (2017). Kesesuaian antara Tuntutan Liturgi dengan Konfigurasi Spasial dan Bentuk Bangunan Arsitektur Gereja Katolik. Universitas Katolik Parahyangan Bandung.

Trisno, R., Antariksa, \& Salura, P. (2014). Sacred Existensial Expression of the Cathedral Church on the Jalan Katedral No.7 - Jakarta. International Journal of Academic Research, 6(6), 218-221.

Trisno, R., Antariksa, \& Salura, P. (2015). The Harmony between the Sacred Function and the Expression Form in Santo Matias Rasul Church.
Journal of Applied Environmental and Biological Sciences, 5(11), 100-104.

Turner, R. W. J. (2000). Catholic Identity, the Building, the Reactions: A Viewpoint from Anthropology. Sacred Architecture, 27-28.

Verkaaik, O. (2013). Anthropological Perspectives. In O. Verkaaik (Ed.), Religious Architecture, 7-24. Amsterdam University Press. https://doi. org/10.1007/978-3-319-14454-2_15

Ward, P. (2001). Liquid Church. Michigan: Baker Books. 